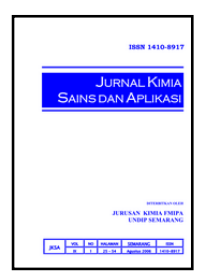

\title{
Pemanfaatan Karbon Aktif Serbuk Gergaji Kayu Jati untuk Menurunkan Chemical Oxygen Demand (COD) Limbah Cair Industri Tekstil
}

\author{
Ratu Yulia Akhsanti ${ }^{\text {a }}$, Retno Ariadi Lusiana ${ }^{{ }^{*}}$, Khabibi ${ }^{\text {a }}$ \\ a Analytical Chemistry Laboratory, Chemistry Department, Faculty of Sciences and Mathematics, Diponegoro University, Jalan Prof. \\ Soedarto, Tembalang, Semarang 50275 \\ * Corresponding author: retno.lusiana@live.undip.ac.id
}

\begin{tabular}{ll} 
Article Info & Abstract \\
\cline { 1 - 2 } $\begin{array}{l}\text { Keywords: } \\
\text { activated carbon, } \\
\text { adsorption, }\end{array}$ & $\begin{array}{l}\text { The use of activated carbon from teak sawdust with activating agent NaCl solution to } \\
\text { decrease COD of textile industry liquid waste has been studied. The results showed that } \\
\text { the activated carbon had ash content of } 1.05 \% \text { and water content of } 3.82 \% \text {. FTIR spectra } \\
\text { shemical Oxygen }\end{array}$ \\
$\begin{array}{l}\text { showed the presence of functional group of hydroxyl group while from SEM analysis, it } \\
\text { was obtained the pore diameter of activated carbon of } 0.468 \mu \mathrm{m} \text { and length of } 0.489 \mu \mathrm{m} .\end{array}$ \\
$\begin{array}{l}\text { At the time of adsorption of } 110 \text { minutes there was a decrease of COD content by } 86 \% \\
\text { and at the weight of adsorbent } 1.15 \text { gram there was a decrease of COD content by } 84 \% \\
\text { from the initial COD level of textile industry waste of } 1291,53 \mathrm{mg} / \mathrm{L} .\end{array}$
\end{tabular}

\begin{abstract}
Abstrak
Pada penelitian ini dikaji penggunaan karbon aktif dari serbuk gergaji kayu jati dengan zat pengaktifasi berupa larutan $\mathrm{NaCl}$ untuk menurunkan COD limbah cair industri tekstil. Hasil penelitian menunjukkan bahwa karbon aktif dari serbuk gergaji kayu jati memiliki kadar abu 1,05\% dan kadar air 3,82\%. Spektra FTIR menunjukkan adanya gugus fungsi berupa gugus hidroksil sementara dari analisis SEM, diperoleh ukuran pori karbon aktif dengan diameter 0,468 $\mu \mathrm{m}$ dan panjang 0,489 $\mu \mathrm{m}$. Pada waktu adsorpsi 110 menit terjadi penurunan kadar COD sebesar $86 \%$ dan pada berat adsorben 1,15 gram terjadi penurunan kadar COD sebesar $84 \%$ dari kadar COD awal limbah industri tekstil sebesar 1291,53 mg/L.
\end{abstract}

Kata kunci: karbon aktif, adsorpsi, Chemical Oxygen Demand (COD)

\section{Pendahuluan}

Chemical Oxygen Demand (COD) merupakan parameter pencemaran air oleh senyawa organik yang secara ilmiah dapat teroksidasi melalui proses mikrobiologis dengan adanya oksigen dalam air, sehingga menyebabkan berkurangnya ketersediaan oksigen terlarut dalam air. Dengan melihat angka COD, maka akan diketahui tingkat pencemaran yang terdapat pada limbah cair. Untuk itu perlu suatu penelitian untuk membantu lingkungan menurunkan kadar COD.

Ada beberapa metode yang dapat digunakan untuk menurunkan kadar COD limbah cair industri tekstil, diantaranya dengan elektrolisis, resin penukar ion dan adsorpsi. Salah satu metode adsorpsi yang dapat digunakan untuk menurunkan COD adalah penjerapan melalui karbon aktif yang dibuat dari serbuk gergaji yang berasal dari limbah kayu jati. Limbah kayu jati yang berupa serbuk gergaji merupakan bahan yang mengandung karbon sehingga dapat diproses untuk menghasilkan karbon aktif. Karbon aktif ini berasal dari dekomposisi termal selulosa, hemiselulosa dan lignin yang telah mengalami proses aktifasi.

Karbon aktif dapat dibuat dari serbuk gergaji yang telah mengalami proses pirolisis dan direndam dalam bahan pengaktif. Bahan pengaktif yang banyak digunakan antara lain: $\mathrm{NaCl}, \mathrm{ZnCl}_{2}, \mathrm{H}_{2} \mathrm{SO}_{4}, \mathrm{H}_{3} \mathrm{PO}_{4}$, $\mathrm{Ca}(\mathrm{OCl})_{2}$ dan $\mathrm{NaOH}$. Proses pembuatan karbon aktif 
dilakukan dengan aktifasi secara kimia. Pembuatan karbon aktif secara kimia dilakukan melalui perendaman pada zat pengaktifasi untuk melarutkan pengotor-pengotor dalam pori-pori karbon aktif sehingga luas permukaan dan ukuran pori lebih besar [1].

Beberapa penelitian tentang pembuatan karbon aktif dari serbuk gergaji telah dilakukan dengan memanfaatkan limbah kayu untuk pembuatan arang aktif melalui tahap pirolisis dan tahap aktifasi. Aktivator yang digunakan adalah $\mathrm{Na}_{2} \mathrm{CO}_{3}$ dan produk karbon aktif yang dihasilkan mempunyai kadar air 3,32-8,48\% dan kadar abu 2,2\% [2]. Dari beberapa penelitian menunjukkan bahwa karbon aktif dari serbuk gergaji memiliki peluang yang cukup besar dengan rendemen berkisar $54,12-64,41 \%$ [2]. Pada penelitian selanjutnya dengan membuat karbon aktif dari pohon palm babassu dan tempurung kelapa menghasilkan kadar abu tinggi. Karbon aktif dari pohon palm babassu memiliki kadar abu 5,65\% dan pada tempurung kelapa mencapai $6,49 \%$ [3]. Sedangkan penelitian yang dilakukan dengan variasi temperatur pirolisis $300^{\circ} \mathrm{C}, 350^{\circ} \mathrm{C}, 400^{\circ} \mathrm{C}$ dengan aliran konstan nitrogen didapatkan hasil adsorpsi yang tinggi pada temperatur $400^{\circ} \mathrm{C}[4]$.

Pada penelitian ini akan dilakukan pembuatan karbon aktif dari serbuk gergaji kayu jati dengan aktifasi menggunakan larutan $\mathrm{NaCl}$. Larutan $\mathrm{NaCl}$ dipilih karena sifatnya mirip dengan $\mathrm{Na}_{2} \mathrm{CO}_{3}$ yaitu garam yang sifatnya netral. Juga karena mudah didapatkan dan lebih ekonomis. Aktifasi dilakukan melalui perendaman karbon hasil pirolisis pada larutan $\mathrm{NaCl} 5 \mathrm{M}$ selama 24 jam. Larutan $\mathrm{NaCl}$ akan melarutkan mineral-mineral anorganik yang masih tertinggal setelah proses pirolisis. Sehingga diharapkan pori-pori karbon aktif menjadi lebih besar dan lebih banyak, yang dapat dilihat melalui analisis SEM.

Karbon aktif hasil sintesis akan diaplikasikan untuk penurunan COD pada air limbah industri tekstil. Senyawa organik yang berada pada limbah tekstil akan dijerab melalui pori-pori karbon aktif hingga karbon aktif mencapai titik jenuh (tidak terjadi adsorpsi). Penurunan COD ini harus kurang dari $300 \mathrm{mg} / \mathrm{L}$, dimana batas ini merupakan batas maksimum kadar COD yang aman dibuang ke lingkungan sesuai Keputusan Menteri Negara Lingkungan Hidup Nomor: Kep51/MENLH/10/1995 [5]

\section{Metodologi Penelitian}

Peralatan yang digunakan dalam penelitian ini meliputi: peralatan gelas, 1 set refluks, kertas $\mathrm{pH}$, furnace, timbangan analitik, pemanas listrik, batch shaker, FTIR Shimadzu dan Scanning Electron Microscopy (SEM) JEOL jsm-6360 LA. Bahan yang akan digunakan dalam penelitian ini i: sampel air limbah industri tekstil, serbuk gergaji kayu jati, $\mathrm{NaCl}$ (p.a), larutan standar $\mathrm{K}_{2} \mathrm{Cr}_{2} \mathrm{O}_{7}$ (p.a), $\mathrm{Ag}_{2} \mathrm{SO}_{4}$ (p.a), $\mathrm{H}_{2} \mathrm{SO}_{4}$ 95-97\%, Fero Amonium Sulfat (FAS), indikator feroin dan akuades.

\section{Proses Pembuatan Karbon Serbuk Gergaji Kayu Jati}

Serbuk gergaji dikeringkan pada suhu $110^{\circ} \mathrm{C}$ selama 4 jam. Kemudian dipirolisis pada suhu $400^{\circ} \mathrm{C}$ dengan aliran konstan nitrogen selama 2 jam.

\section{Proses Aktifasi Karbon Serbuk Gergaji Kayu Jati}

Sebanyak 45 gram karbon (100 mesh) direndam dalam aktivator $\mathrm{NaCl} 5 \mathrm{M}$ selama 24 jam, selanjutnya karbon aktif disaring dan dicuci dengan akuades. Karbon aktif yang dihasilkan kemudian dikeringkan dalam oven pada suhu $110^{\circ} \mathrm{C}$ selama 4 jam, selanjutnya dimasukkan dalam desikator.

\section{Karakterisasi Karbon Aktif}

Karbon aktif yang dihasilkan, dikarakterisasi yang meliputi penentuan kadar abu, kadar air, gugus aktif yang terdapat dalam struktur karbon aktif dengan FTIR dan pori-pori karbon aktif dengan SEM.

\section{Proses Adsorpsi oleh Karbon Aktif}

Sebanyak 1,15 gram karbon yang telah diaktifasi dimasukkan dalam erlenmeyer $250 \mathrm{~mL}$ dan ditambahkan $100 \mathrm{~mL}$ sampel limbah cair yang sudah ditentukan terlebih dahulu kadar COD. Kemudian proses adsorpsi dilakukan dengan metode batch-shaker dengan variasi berat karbon aktif 0,$1 ; 0,15 ; 0,25 ; 0,4 ; 0,6 ; 0,8$; 1,15 gram yang digunakan sebagai adsorben dan variasi waktu kontak 5, 10, 20, 35, 55, 80, 110 menit pada temperatur kamar. Setelah disaring, filtrat diukur kadar COD dengan metode titrimetri dengan larutan FAS sebagai titrannya.

\section{Analisis COD dengan Titrasi Fero Amonium Sulfat (FAS)}

Sebanyak $3 \mathrm{~mL}$ sampel air limbah dengan variasi waktu dan variasi karbon aktif yang ditambahkan, masing-masing masukkan dalam alat refluks kemudian masing-masing ditambahkan dengan $1,5 \mathrm{~mL} \mathrm{~K}_{2} \mathrm{Cr}_{2} \mathrm{O}_{7}$ $0,25 \mathrm{~N}$ dan 3,5 $\mathrm{mL}$ pereaksi asam sulfat. Setelah itu direfluks pada suhu $148^{\circ} \mathrm{C}$ selama 2 jam, lalu didinginkan pada suhu kamar. Setelah itu larutan dipindahkan dalam erlenmeyer dan ditambah 1-2 tetes indikator feroin. Selanjutnya dititrasi dengan larutan FAS 0,1 $\mathrm{N}$ sampai warna berubah menjadi merah bata. Cara yang sama dilakukan untuk blanko tetapi sampel diganti dengan akuades.

\section{Hasil dan Pembahasan}

\section{Pembuatan Karbon Serbuk Gergaji Kayu Jati}

Serbuk gergaji kayu jati dimasukkan dalam oven pada suhu $110^{\circ} \mathrm{C}$ selama 4 jam. Tujuan pemanasan ini untuk menguapkan kandungan air dan menurunkan kelembaban sampel. Kemudian serbuk gergaji yang telah kering tersebut dipirolisis pada suhu $400^{\circ} \mathrm{C}$ selama 2 jam dengan mengalirkan gas nitrogen. Hal ini dilakukan untuk mendorong senyawa-senyawa volatile sehingga abu yang terbentuk hanya sedikit karena pembentukan abu dapat menutupi pori-pori arang yang dihasilkan. Pada proses ini dihasilkan karbon. 
Proses selanjutnya adalah aktifasi, karbon yang telah jadi direndam pada aktivator berupa larutan $\mathrm{NaCl}$ selama 24 jam yang bertujuan untuk melarutkan pengotor-pengotor yang terdapat pada permukaan karbon aktif sehingga pori-pori dapat terbuka. Dengan perendaman ini pergerakan senyawa-senyawa volatil melalui bagian pori karbon aktif tidak akan terhalangi dan akhirnya senyawa ini akan dilepaskan dari permukaan karbon selama proses aktifasi [6].

\section{Karakteristik Karbon Aktif}

Tabel 1. Karakteristik Karbon Aktif

\begin{tabular}{cc}
\hline Jenis uji & Hasil \\
\hline Kadar air & $3,82 \%$ \\
Kadar abu & $1,05 \%$ \\
\hline
\end{tabular}

Kadar air merupakan salah satu parameter standarisasi karbon aktif. Dari tabel 1 dapat dilihat kadar air karbon aktif sebesar 3,82\%. Pengujian kadar air dilakukan dengan memanaskan karbon aktif pada suhu $110^{\circ} \mathrm{C}$ selama 4 jam yang mengakibatkan kandungan air dalam karbon aktif semakin rendah. Hal ini disebabkan karena pada temperatur di atas $100^{\circ} \mathrm{C}$, air mulai berubah fasa menjadi uap, sehingga sejumlah air menguap dari karbon aktif.

Keberadaan air dapat menutupi pori-pori karbon aktif, sehingga kadar air yang rendah menjadikan poripori karbon aktif semakin besar. Semakin besar poripori yang terbuka maka luas permukaan karbon aktif semakin bertambah. Bertambahnya luas permukaan ini akan meningkatkan kemampuan adsorpsi dari karbon aktif.

Kadar air karbon aktif yang diizinkan maksimal $10 \%$ [5]. Dengan demikian, perolehan kadar air karbon aktif yang dihasilkan jauh di bawah harga maksimum (10\%), maka kadar air karbon aktif yang dihasilkan pada penelitian ini telah memenuhi standar mutu karbon aktif.

Parameter lain yang juga mempengaruhi kualitas karbon aktif adalah kadar abu. Pengujian kadar abu dilakukan dengan memanaskan karbon aktif dalam furnace pada suhu $750^{\circ} \mathrm{C}$ selama 4 jam. Dari tabel 1 dapat dilihat kadar abu yang diperoleh sebesar 1,05\%.

Karbon aktif terdiri dari lapisan-lapisan bertumpuk satu sama lain yang membentuk pori, pada pori-pori karbon aktif biasanya terdapat pengotor. Selama proses aktifasi, pengotor tersebut larut dalam aktivator sehingga menyebabkan pori-pori semakin besar. Hal ini mengakibatkan semakin besar luas permukaan karbon aktif yang diikuti semakin baik kualitas karbon aktif.

Penentuan gugus aktif pada karbon aktif dilakukan dengan menggunakan FTIR. Analisis ini dibandingkan dengan melihat gugus aktif sebelum proses pengaktifasian dan gugus aktif setelah proses pengaktifasian dengan zat kimia berupa larutan $\mathrm{NaCl}$. Hasil analisis karbon aktif sebelum aktifasi dan sesudah aktifasi dengan FTIR dapat dilihat pada gambar 1 dan 2 .

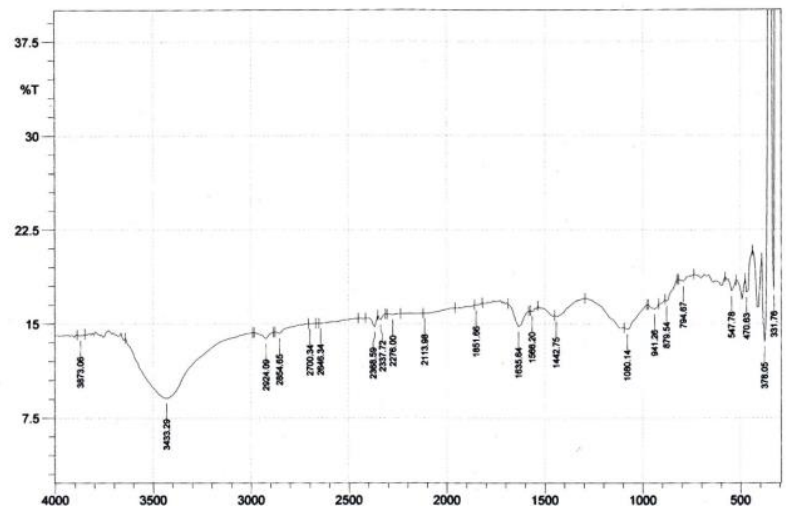

Gambar 1. Spektra FTIR Karbon Aktif sebelum Aktifasi dengan Larutan $\mathrm{NaCl}$

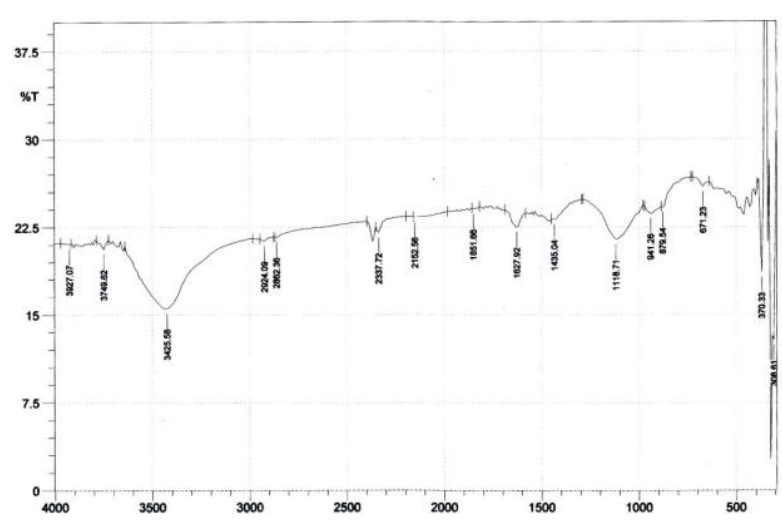

Gambar 2. Spektra FTIR Karbon Aktif setelah Aktifasi dengan Larutan $\mathrm{NaCl}$

Tabel 2. Prediksi Gugus Fungsi pada Karbon Aktif sebelum Proses Aktifasi dengan Analisis menggunakan FTIR

\begin{tabular}{lcc}
\hline \multicolumn{1}{c}{ Gugus Fungsi } & Ikatan & Puncak, $\mathrm{cm}^{-1}$ \\
\hline $\begin{array}{l}\text { Konjugasi } \\
\text { Alkena }\end{array}$ & $\mathrm{C}=\mathrm{C}$ (streching) & 1442.75 \\
Cincin Aromatik & $\mathrm{C}=\mathrm{C}$ (streching) & 1635.34 \\
Gugus Hidroksil & O-H & 3433.29 \\
\hline
\end{tabular}

Tabel 3. Prediksi Gugus Fungsi pada Karbon Aktif setelah Proses Aktifasi dengan Analisis menggunakan FTIR

\begin{tabular}{lcc}
\hline \multicolumn{1}{c}{ Senyawa } & Ikatan & Puncak, $\mathrm{cm}^{-1}$ \\
\hline $\begin{array}{l}\text { Konjugasi } \\
\text { Alkena }\end{array}$ & $\mathrm{C}=\mathrm{C}($ streching $)$ & 1435.04 \\
Cincin Aromatik & $\mathrm{C}=\mathrm{C}$ (streching) & 1627.92 \\
Gugus Hidroksil & $\mathrm{O}-\mathrm{H}$ & 3425.58 \\
\hline
\end{tabular}

Dalam Spektra FTIR karbon aktif sebelum adsorpsi pada gambar 1 terlihat adanya pita serapan melebar pada daerah 3433,29 $\mathrm{cm}^{-1}$ yang menunjukkan adanya gugus hidroksil $(-\mathrm{OH})$, pita serapan medium pada daerah $1635,34 \mathrm{~cm}^{-1}$ menunjukkan gugus $\mathrm{C}=\mathrm{C}$ pada senyawa aromatik dan pita serapan pada daerah 1442,75 $\mathrm{cm}^{-1}$ dihasilkan oleh konjugasi alkena. Pada gambar 2 serapan yang dihasilkan sama dengan serapan pada gambar 1.

Dengan melihat kedua gambar tersebut tidak terjadi perubahan yang signifikan antara gugus fungsi karbon 
aktif sebelum dan sesudah aktifasi. Ini dikarenakan proses aktifasi dengan larutan $\mathrm{NaCl}$ lebih banyak berperan untuk melarutkan pengotor-pengotor yang ada di dalam pori-pori karbon aktif sehingga pori-pori karbon aktif menjadi terbuka.

Dari hasil analisis SEM dengan perbesaran 5000x, 2500x, 2000x dan 200x diperoleh data pada gambar 3 . Dari data tersebut menunjukkan bahwa karbon aktif serbuk gergaji kayu jati mempunyai ukuran pori yaitu lebar 0,468 $\mu \mathrm{m}$ dan panjang 0,489 $\mu \mathrm{m}$. Dengan diketahuinya ukuran pori dari karbon aktif ini menyebabkan karbon aktif mampu menyerap senyawasenyawa organik yang terdapat pada air limbah industri tekstil.
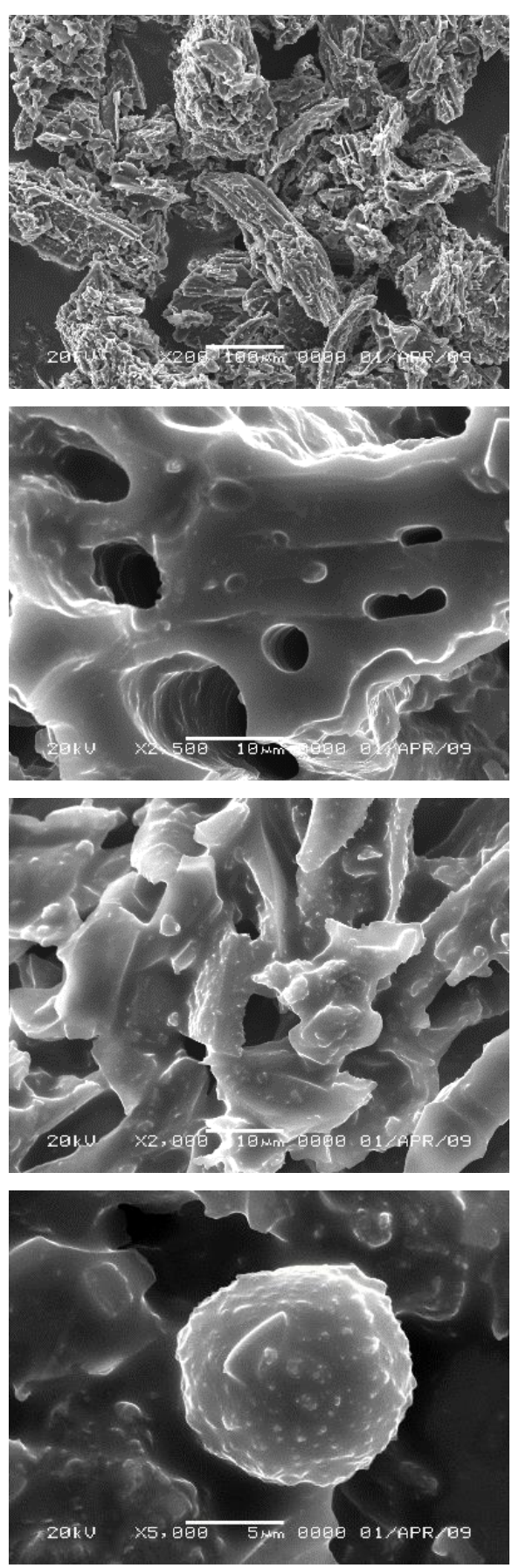

Gambar 3. Morfologi SEM Karbon Aktif
Luas permukaan merupakan salah satu karakteristik yang paling penting yang berhubungan langsung terhadap kemampuan adsorpsi karbon aktif terhadap zat-zat yang akan dijerap.

Pirolisis menyebabkan bahan-bahan volatil banyak yang menguap sehingga banyak kisi-kisi aktif (poripori) yang terbentuk. Semakin besar permukaan suatu karbon aktif maka kapasitas adsorpsinya akan semakin besar. Karena bila karbon aktif memiliki luas permukaan besar akan memberikan bidang kontak yang lebih besar antara adsorben dan adsorbatnya, sehingga adsorbat dapat terjerap lebih banyak. Pori-pori karbon memiliki diameter yang beragam, sehingga penjerapan juga tidak seragam.

Penurunan Angka COD pada Air Limbah Industri Tekstil dengan Karbon Aktif

Salah satu parameter yang digunakan untuk mengetahui kualitas limbah adalah dengan mengukur kadar COD. Karbon yang telah diaktifkan dapat dipakai untuk menurunkan kadar COD pada limbah cair industri tekstil. Kadar COD awal limbah cair industri tekstil sebesar 1291,53 mg/L. Setelah proses adsorbsi dengan karbon aktif, kadar COD ini turun hingga hampir $90 \%$. Penurun ini menjadikan limbah cair industri tekstil aman untuk dibuang ke lingkungan, dimana batas maksimum kadar COD yang diijinkan adalah sebesar 300 $\mathrm{mg} / \mathrm{L}$ [5].

\section{Pengaruh Waktu Kontak terhadap Penurunan COD}

Salah satu variasi yang digunakan adalah waktu kontak, dimana variasi waktu kontak adalah 5, 10, 20, 35, 55, 80, 110 menit. Tujuan variasi waktu kontak adalah untuk mengetahui waktu optimal adsorben dalam menjerab adsorbat. Dimana semakin lama waktu yang dikontakkan adsorben pada adsorbat maka semakin banyak adsorbat yang teradsorb, sehingga kuantitas adsorbsi semakin besar dan hampir konstan setelah mencapai kesetimbangan [7]. Dengan menggunakan 1,15 gram karbon aktif, didapatkan waktu optimal pada 110 menit. Hal ini dapat disimpulkan dengan melihat kurva yang dihasilkan dimana sudah hampir mendatar total dari menit ke 80 sampai dengan 110. Kadar COD turun menjadi 190,14 mg/L, ini berarti terjadi penurunan sebesar $86 \%$.

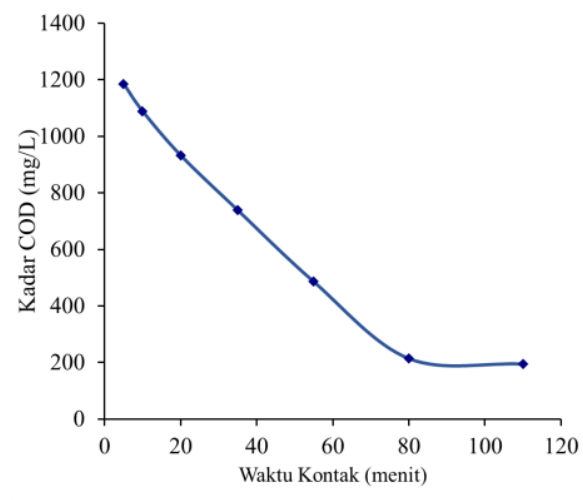

Gambar 4. Grafik Hubungan Waktu Kontak dan Kadar COD Limbah Cair Industri Tekstil 
Pada kurva ini dihasilkan suatu garis tunggal dan lurus dalam hubungan antara waktu kontak dengan kadar zat yang diadsorpsi hingga tercapai suatu titik jenuh berupa garis mendatar. Ini sesuai dengan penelitian yang dilakukan oleh Badmus $d k k$. [8]. Laju penurunan yang cepat pada awal adsorpsi mungkin dikarenakan kemampuan dari permukaan karbon aktif yang masih terbuka [8]. Kurva akan mendatar (tidak terjadi adsorpsi), ketika lapisan tunggal (monolayer) zat organik telah menutupi seluruh permukaan karbon aktif dengan sempurna.

\section{Pengaruh Berat Adsorben terhadap Penurunan COD}

Variasi selanjutnya adalah berat adsorben, dimana variasi berat adsorben adalah 0,$1 ; 0,15 ; 0,25 ; 0,4 ; 0,6$; 0,$8 ; 1,15$ gram. Tujuan variasi berat adsorben adalah untuk mengetahui berat adsorben yang dapat menjerab adsorbat secara maksimal hingga adsorben mengalami titik jenuh. Semakin banyak adsorben yang dikontakkan pada adsorbat maka semakin banyak adsorbat yang teradsorb, sehingga kuantitas adsorbsi semakin besar. Dengan waktu kontak selama 110 menit, didapatkan kuantitas adsorpsi terbesar pada penjerapan melalui karbon aktif seberat 1,15 gram. Hal ini dapat disimpulkan dengan melihat kurva pada gambar 5 . Kadar COD turun menjadi $188,34 \mathrm{mg} / \mathrm{L}$, ini berarti terjadi penurunan sebesar $84 \%$.

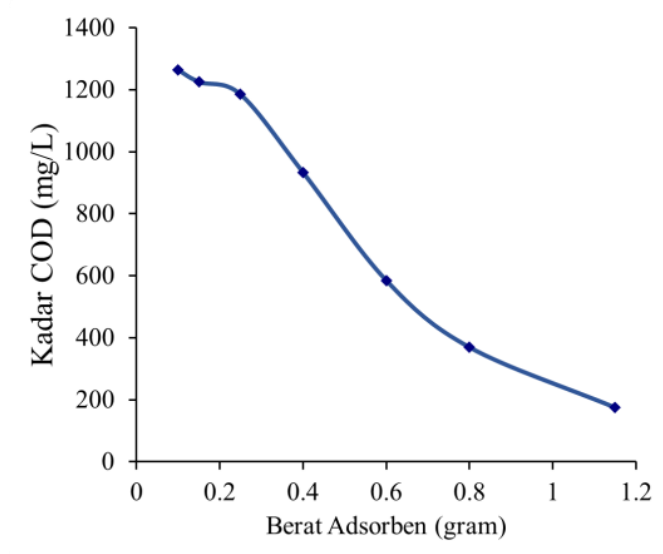

Gambar 5. Grafik Hubungan Berat Adsorben dan Kadar COD Limbah Cair Industri Tekstil

\section{Kesimpulan}

Telah dihasilkan karbon aktif dari serbuk gergaji kayu jati dengan aktivator $\mathrm{NaCl}$. Kadar abu dari karbon aktif serbuk gergaji kayu jati sebesar 1,05\%, sedangkan kadar air sebesar 3,82\%. Kadar COD awal limbah industri tekstil sebesar 1291,53 mg/L. Waktu kontak optimal dihasilkan pada 110 menit dengan penurunan kadar COD sebesar $86 \%$ dan pada berat adsorben 1,15 gram terjadi penurunan kadar COD hingga $84 \%$.

\section{Daftar Pustaka}

[1] Muslim, Karakterisasi Karbon Aktif dari Green Coke dengan Perlakuan Kimia (NaOH), Skripsi, Jurusan Kimia, Universitas Diponegoro, Semarang

[2] Rini Pujiarti, J. P. Gentur Sutapa, Mutu Arang Aktif dari Limbah Kayu Mahoni (Swietenia macrophylla
King) sebagai Bahan Penjernih Air, Jurnal Ilmu dan Teknologi Kayu Tropis, 3, 2, 33-38

[3] E. F. Jaguaribe, L. L. Medeiros, M. C. S. Barreto, L. P. Araujo, The Performance of Activated Carbons From Sugarcane Bagasse, Babassu, and Coconut Shells in Removing Residual Chlorine, Brazilian Journal of $\begin{array}{lllll}\text { Chemical Engineering, 22, (2005) 41-47 } & 4\end{array}$ http://dx.doi.org/10.1590/S010466322005000100005

[4] M. A. Rahman, M. Asadullah, M. M. Haque, M. A. Motin, M. B. Sultan, M. A. K. Azad, Preparation and characterization of activated charcoal as an adsorbent, Journal of Surface Science and Technology, 22, 3/4, (2006) 133-140

[5] Keputusan Menteri Negara Lingkungan Hidup in: K.N.L. Hidup (Ed.) No. KEP-51/MENLH/10/1995, Jakarta, 1995.

[6] W. B Wan Nik, M. M. Rahman, A.M. Yusof, F.N. Ani, C. M. Che Adnan, Production of Activated Carbon from Palm Oil Shell Waste and Its Adsorption Characteristics, in: The 1st International Conference on Natural Resources Engineering \& Technology, Putrajaya, Malaysia, 2006, pp. 646654 .

[7] Ola Abdelwahab, Ahmed El Nemr, Amany El-Sikaily, Azza Khaled, Use of rice husk for adsorption of direct dyes from aqueous solution: A case study of direct F. Scarlet, in: The 1st International conference on aquatic resources of the Arab Region, 2005, pp. 110.

[8] M. A. O. Badmus, T. O. K. Audu, B. U. Anyata, Removal of Lead Ion From Industrial Wastewaters by Activated Carbon Prepared from Periwinkle Shells (Typanotonus Fuscatus), Turkish Journal of Engineering and Environmental Sciences, 31, 4, (2007) 251-263 